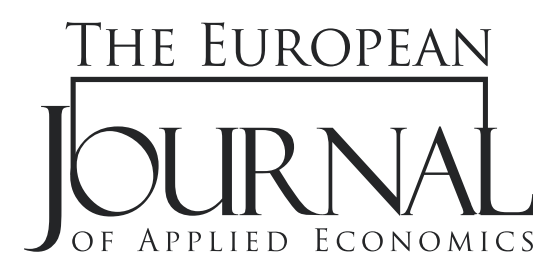

EJAE 2021, 18(1): 137 - 150

ISSN 2406-2588

UDK: 658.62

659.113 .25

DOI: 10.5937/EJAE18-28972

Original paper/Originalni naučni rad

\title{
THE EFFECT OF COUNTRY - OF - ORIGIN IMAGE TROUGH QUALITY, DESIGN AND ATTRACTIVENESS RELATED TO PRODUCT ON CONSUMER LOYALTY
}

\author{
Srđan Šapić, Jovana Lazarević* , Jovana Filipović \\ Faculty of Economics, \\ University of Kragujevac, \\ Kragujevac, Serbia
}

\begin{abstract}
:
The main goal of this research is to determine whether there is an impact of country - of- origin image on consumer loyalty to products originating from countries with positive and recognizable image and whether this impact is achieved through characteristics such as product quality and design, and attractiveness related to using the same. To examine this impact, an empirical study was conducted on a sample of 150 respondents and analysis of collected data was performed in SPSS 20. The results show that information about country- of -origin image is important to consumers and has an impact on their behavior related to buying foreign product. More precisely, results show that country -of- origin image affects consumers when they choose products based on their quality and design and attractiveness that consumers feel when using these products, and also that through these characteristics country -of -origin image has effects on consumer loyalty. In accordance with the obtained results, conclusion is that it is extremely desirable for companies and governments to take into account the image that their country enjoys on the world market.
\end{abstract}

Article info:

Received: October 23, 2020

Correction: December 16, 2020

Accepted: February 8, 2021

\section{Keywords:}

country -of -origin image, product quality, product design, attractiveness, consumer loyalty.

\section{INTRODUCTION}

The concept of country -of -origin image is one of the most famous concepts that has been researched in social sciences. Concept developed when manufacturers began to internationalize their activities and export products to foreign markets, where they had to comply with certain legal requirements and indicate product country- of -origin on packaging or product itself. Initially, this information was just a way to identify the origin of product. However, over time, consumer behavior researchers and marketers have realized that country- of -origin image, as the image that individuals have about a country, is information that is important for consumers when making decision to buy foreign product. 
Consumer country information is an indicator of product superiority, quality and acceptability. When consumers choose between several alternative foreign products, countries image they come from will influence consumers to perceive these products completely differently. However, whether and in what way consumers will use the information about country -of -origin image for product they want to buy, depends on numerous factors such as the type of product, consumer experience in relation to that or other products originating from a certain country, etc. Consumers may also be influenced by positive or negative stereotypes about certain countries that are passed on to its products (Aichner, 2014). When consumers have positive image of a country and its products, they are ready to buy such products again because in that way they avoid risk of making the wrong choice. Research shows that consumer attachment to products originating from a country towards which they have positive attitude is a consequence of positive perception of product characteristics, with products from certain countries being considered to be of high quality, attractive design and high technological development (Ahmed \& d'Astous, 2015; Coudounaris, 2018; Karimov \& El-Murad, 2019).

The effect of country -of -origin image on consumer perception is influenced by certain factors (Thøgersen et al., 2020). This effect primarily differs depending on type and characteristics of the product. Then, information about the economy, social and cultural system enables consumers to position countries in their consciousness and assess their image on that basis. Finally, the demographic and socio-psychological characteristics of consumers significantly affect their perception of countries and products that come from them. Despite numerous studies on effect of country- of -origin image in past decades, there are certain limitations of the same. One of the main limitations is that previous research has been conducted mainly in specific geographical areas, most often developed countries (Sharma, 2011), whose results are often generalized. Another problem related to previous research involves predominantly examining effect of country -of- origin image depending on different product categories, making it difficult to obtain generalisations when it comes to product categories that are not immediately linked to a country -of -origin image (Tseng \& Balabanis, 2011). In order to overcome above mentioned limitations, it is recommended to conduct new research related to observed issues. Based on the above, a research was conducted in order to determine whether country -of -origin image affects consumer loyalty, not emphasizing special product categories but looking at the purchase of any foreign product in the Republic of Serbia as a transition economy. Further, research takes into account the impact of country -of origin -image on quality and design as product characteristics and attractiveness that consumers feel using them, and examines how important these characteristics are when it comes to consumer loyalty. The rest of the article is divided as follows: the first part refers to literature review and includes brief overview of theoretical findings that were used in determining goal and defining research hypotheses. The second part presents methodology i.e. analyzes that were conducted during research. The following section describes a sample of respondents from whom primary data were collected. The fourth part includes obtained results and their discussion. The last part of the article presents the most important conclusions about obtained results and provides guidelines for future research. 


\section{LITERATURE REVIEW AND HYPOTHESES DEVELOPMENT}

Place in the world where certain product is produced or its source of origin is called country of origin (Parkvithee \& Miranda, 2012). In today's world economy, many products consist of parts that are produced in different countries, but these parts are assembled into the final product in a particular country. Manufacturers take care that country in which final product is assembled is country of origin of products that consumers in most parts of the world perceive as country that produces products of high quality, reliability or technological sophistication. In this way, producers take advantage of effect of country -of -origin image and influence that it can have on perception of consumers and their decision-making when buying foreign products. There are several definitions of effect of country -of -origin image. One is that this effect is the picture, the reputation, the stereotype that businessmen and consumers attach to products of a specific country (Nagashima, 1970, p. 68). It is also defined as the influence on a buyer considering a product or service from another country due to the stereotyping of that country and its outputs (Suh et al., 2016, p. 2721). In this regard, country -of -origin image has substantially the same influence on consumer product evaluation compared to other product functions (Katsumata \& Song, 2015). In general, country -of -origin image is a multidimensional category that affects consumers so that they form a perception of products they know that come from a particular country, and then transfer that perception to other products from that country. In other words, information about country of origin provide consumers a summary of constructs of the actual product atributes and have important role in product evaluation and overall consumer behaviour (Cilingir \& Basfirinci, 2014).

Country -of- origin image determines products on three levels: cognitive, affective and normative (Rashid, 2017). At cognitive level, country of origin is crucial when looking at product quality, with the proviso that one can speak of design quality and manufacturing quality. In case of affective level, country of origin influences the development of symbolic and emotional connotation of product and provides consumers with benefits in form of status or pride. When we look at normative level, we actually mean the degree of consumer ethnocentrism, i.e. his desire to support development of the economy by buying domestic products. Taking into account importance of country -of -origin image for formation of consumer perceptions about products, Karimov \& El-Murad (2019) indicate presence of significant relationships between country of origin and evaluation of product quality. Klöckner et al. (2013) confirm presence of effect of country -of -origin image on quality evaluation related to pepper. Khan et al. (2012) in their research found that consumers consider German products to have a good style, while specifically viewing German cars as a symbol of luxury status. Kreppel \& Holtbrügge (2012) start from the assumption that Chinese products country -of -origin image negatively influences on perceived products attractiveness and confirm that the same differs when it comes to sociopsyhological determinants of German consumers. Starting from the above, a clear relationship can be observed between country -of origin -image and characteristics such as quality, design and attractiveness, i.e. the following can be assumed:

H1: There is a statistically significant effect of country- of -origin image on product related characteristics:

H1a: There is a statistically significant effect of country -of- origin image on product quality;

$H 1 b$ : There is a statistically significant effect of country -of -origin image on product design;

H1c: There is a statistically significant effect of country-of-origin image on the attractiveness that consumers feel due to the use of a particular product. 
According to Zeng et al. (2015), key factors for obtaining sustainable competitive advantage in the market are the ability of the company to develop innovation and quality. Quality is a property of a product on basis of which its value is measured. Antić \& Stevanović (2013) explain quality as all the properties and characteristics of products, processes and activities that are related to meeting certain consumer needs. The importance of quality is reflected in the fact that it can greatly contribute to achieving a competitive advantage in the market. The first determinant of overall consumer satisfaction is precisely perceived product quality, the second is perceived value and the third is consumer expectations (Fornell et al., 1996). High-quality products whose quality is constantly maintained and improved, again and again meet or exceed the expectations of consumers, which consequently leads to their satisfaction and, in the long run, their loyalty. As consumer loyalty is the basis of long-term profitability, companies are aware of how important it is to provide consumers with product quality they expect in order to bond with the company and its products in the long run. Assumptions about product quality effects on development of consumer loyalty have been empirically confirmed in numerous studies (Erdoğmuş \& Büdeyri-Turan, 2012; Mohd Suki, 2017; Esmaeilpour, 2015; Gómez et al., 2018; Shanahan et al., 2019). Product design is one of the possibilities for strengthening competitiveness of both country's economy and its companies. At the beginning of the $21^{\text {st }}$ century, design, through fashion, home products to mobile phones and computers, has become a key factor in the world of consumers. As aesthetic demands of consumers grow, so does the quality of design, because it is clear that consumer's choice of a brand can be influenced by product design as important brand-related stimuli (Ramaseshan \& Stein, 2014). Lusch \& Swan (2011, p. 338) define design as the set of properties of an artifact, consisting of the discrete properties of the form (i.e., the aesthetics of the tangible good and/or service) and the function (i.e., its capabilities) together with the holistic properties of the integrated form and function. The importance of design is reflected in the fact that it creates added value by differentiating products on the market, and differentiation consequently leads to creation of a competitive advantage. Design contributes to achieving a better market position because it primarily emphasizes product quality and influences consumer behavior. Design enriches product and additionally attracts attention of consumers, which affects their desire to buy product and their willingness to recommend it (Gul Gilal et al., 2018). Consumers are considered to see aesthetically designed and engineered products as products that are easier to use compared to those that lack such features. Better designed products are more desirable in the eyes of consumers, there will be positive reactions from them and feeling of excitement, attachment and attention. The above has been empirically confirmed by authors such as Elbedweihy (2016), Kumar et al. (2018), Hsu et al. (2018) etc. The company success in market competition depends largely on product attractiveness, uniqueness and creativity (Munir et al., 2020). Attractiveness of product largely depends on design, as well as quality and price of product, and presents an incentive for consumers to make initial purchase. Attractiveness of product is often linked to its usability. When consumers start using a product, its attractiveness increases if product is easy to use and if meets consumers needs. Conversely, product that appears attractive at first glance will quickly lose such perception by consumers if it functions inadequately (Maguire, 2004). Furthermore, perceived attractiveness of product is mainly related to its design. Attractive design is one that consumers find likable, simple, harmonious. Reber et al. point out that attractiveness of product design affects consumer purchasing intentions so that an increase in attractiveness leads to an increase in preferences for product and its purchase (cited in: Giese et al., 2014). Perceived attractiveness of product can be reflected in prestige of brand for which in studies of author Jin et al. (2015) and Esmaeilpour (2015) have been shown to have positive impact on consumer loyalty. Interesting results are presented by Kim \& Kim (2020) who show that the attractiveness of Airbnb's rental services has positive impact on consumer loyalty. 
In accordance with previously explained relations related to observed characteristics and consumer loyalty, the paper will examine the following:

H2: Product related characteristics have positive effects on development of consumer loyalty:

H2a: Product quality has positive effects on development of consumer loyalty;

H2b: Product design has positive effects on development of consumer loyalty;

H2c: The attractiveness that consumers feel due to the use of a particular product has positive effects on development of consumer loyalty.

Consumer loyalty can be defined as attachment to a brand or business entity that is based on a strong positive attitude and is manifested in repeated purchases (Marinković, 2012, p. 144). Consumer loyalty brings multiple benefits to a company such as spreading positive word- of- mouth, buying other brands of the company, or greater resilience of loyal consumers to competitive strategies (Mothersbaugh \& Hawkins, 2016). On the other hand, loyalty also brings benefits to consumer, such as avoiding costs related to changing the company, reducing risks when buying, better quality services, etc. (Jobber \& Fahy, 2006). Consumer loyalty is influenced by emotional connection, trust and reliability, care for consumers, knowledge about product, product availability and whether product meets wishes and requirements of consumers (Maričić, 2011). There are several factors that are key to achieving consumer loyalty. The most important factor and basis of loyalty is consumer satisfaction with company's products and services which reflects a person's judgment of a product's perceived performance in relationship to expectations (Kotler \& Keller, 2016, p. 33). Consumer satisfaction is related to product or service quality and if it is missing, consumer loyalty does not develop (adapted according to: Šadić et al., 2016). Brand trust is also recognized as an important factor in building loyalty (Veloutsou, 2015). When looking at relationship between product origin and consumer loyalty, Esmaeilpour \& Ali Abdolvand (2016) empirically confirm the effect of country -of -origin image on consumer loyalty when it comes to luxury products. Authors Šapić et al. (2018) in their work come to the conclusion that quality, design and prestige show statistically significant effects on development of consumer loyalty, while respecting effect of country -of -origin image. Taking into account previously explained relations between country -of -origin image, observed characteristics and consumer loyalty, paper will test the following:

H3: Country -of -origin image shows statistically significant effects on consumer loyalty through characteristics such as quality, design and attractiveness.

\section{RESEARCH METHODOLOGY}

In order to prove the set hypotheses, primary data were collected from the respondents on the territory of Kragujevac and its surroundings in the period from 10 to 25 July 2020. The survey was conducted using questionnaire technique, in person. Questionnaire is self-administered, contains 3 demographic questions and 21 seven-point scaled statements in which respondents expressed their degree of agreement with a given statement, where grade 1 indicates absolute disagreement and grade 7 absolute agreement of respondents with the statement. The sample surveyed includes 150 respondents and is segmented based on three demographic criteria such as gender, age, and education. The sample consists of 83 women or $55.3 \%$, while men comprise $44.7 \%$ of the sample (67). The youngest respondents (18 to 35 years) make up $54 \%$ of the sample and there are 81 . Respondents aged 36 to 55 have 49 and they comprise $32.7 \%$ sample, while the oldest respondents, over 56 years, make up $13.3 \%$ of the sample, i.e. there are 20 . 
Regarding segmentation based on education, the largest percentage of the sample are respondents with secondary education, $44 \%$ (66). Higher education has $24.7 \%$ of respondents (37), while 47 respondents have the highest level of education and they cover $31.3 \%$ of the sample.

The statistical method was used for data analysis. The analysis was performed in the statistical software SPSS 20 (Statistical Package for the Social Sciences). In this program, appropriate statistical analyzes were conducted on basis of which conclusions were made. Reliability analysis examined the degree of internal consistency of statements that make up the observed research variables based on which basis for further statistical analysis was provided. The strength of linear or correlation dependence between the observed variables was determined by correlation analysis. Finally, by applying regression analysis, presence of effects of independent variables on dependent ones was tested, i.e. testing of research hypotheses was performed.

\section{RESEARCH RESULTS}

In the continuation of the paper, results of statistical analyzes that were conducted are presented. In this regard, Table 1 presents results of research variables reliability analysis by determining the Cronbach's alpha coefficient. A value of the observed coefficient greater than 0.7 (Nunnally, 1978) represents a minimum acceptable confidence threshold that indicates the internal consistency of statements that make up variables.

Table 1: Reliability analysis

\begin{tabular}{cc}
\hline Variable & Cronbach's alpha \\
\hline Country of origin image & 0.894 \\
\hline Quality & 0.940 \\
\hline Design & 0.893 \\
\hline Attractiveness & $\mathbf{0 . 9 5 6}$ \\
\hline Loyalty & 0.863 \\
\hline
\end{tabular}

Source: authors' calculation

Based on the obtained values of Cronbach's alpha coefficient, it can be noticed that all variables consist of internally consistent statements, i.e. that they meet the initial reliability condition. The highest reliability was found for variable attractiveness, while statements of variable loyalty are the least internally consistent.

In the next step, correlation analysis was performed (Table 2) to determine degree of linear dependence between variables by calculating the Pearson coefficient. The value of this coefficient ranges from - 1 to 1 , where value closer to -1 indicates strong negative correlation and value closer to 1 indicates strong positive correlation. 
Table 2: Correlation analysis

\begin{tabular}{|c|c|c|c|c|c|}
\hline & $\begin{array}{c}\text { Country of } \\
\text { origin image }\end{array}$ & Quality & Design & Attractiveness & Loyalty \\
\hline $\begin{array}{l}\text { Country of } \\
\text { origin image }\end{array}$ & 1 & $0.719^{\star *}$ & $0.642^{\star \star}$ & $0.452^{\star *}$ & $0.506^{* \star}$ \\
\hline Quality & $0.719^{* *}$ & 1 & $0.753^{\star *}$ & $0.427^{\star \star}$ & $0.528^{* *}$ \\
\hline Design & $0.642^{\star *}$ & $0.753^{* *}$ & 1 & $0.465^{\star *}$ & $0.500^{* *}$ \\
\hline Attractiveness & $0.452^{\star *}$ & $0.427^{\star *}$ & $0.465^{\star *}$ & 1 & $0.394^{* *}$ \\
\hline Loyalty & $0.506^{\star *}$ & $0.528^{\star *}$ & $0.500^{\star *}$ & $0.394^{\star *}$ & 1 \\
\hline
\end{tabular}

Source: authors' calculation

** Correlation is significant at the 0.01 level

The correlation matrix shows that Pearson coefficient values between each pair of variables are significant at 0.01 level, i.e. with a probability of $99 \%$. The highest degree of linear dependence is present between variables quality and design $\left(r=0.753^{* *}, p<0.01\right)$ and this is a strong correlation. The variable country -of -origin image is strongly correlated with variables quality $\left(r=0.719^{\star *}, \mathrm{p}<0.01\right)$ and design $\left(\mathrm{r}=0.642^{* *}, \mathrm{p}<0.01\right)$. Moderate correlation is present between variables quality and loyalty $\left(\mathrm{r}=0.528^{* *}, \mathrm{p}<0.01\right)$, country -of -origin image and loyalty $\left(\mathrm{r}=0.506^{* *}, \mathrm{p}<0.01\right)$, design and loyalty $(\mathrm{r}=0.500, \mathrm{p}<0.01)$, then design and attractiveness $(\mathrm{r}=0.465, \mathrm{p}<0.01)$, country -of -origin image and attractiveness $\left(r=0.452^{* *}, p<0.01\right)$ and quality and attractiveness $\left(r=0.427^{\star *}, p<0.01\right)$. Finally, variables attractiveness and loyalty were correlated to the lowest degree $\left(\mathrm{r}=0.394^{* *}, \mathrm{p}<0.01\right)$, i.e. there is a weak correlation between them.

In order to examine influence of independent variable country -of -origin image on dependent variable consumer loyalty indirectly through variables quality, design and attractiveness, regression analysis was performed. The intensity of influence of independent variable is measured by $\beta$ coefficient.

Table 3: Simple regression analysis results (dependent variables: quality, design and attractiveness, respectively)

\begin{tabular}{cccccc}
\hline Variable & $\boldsymbol{\beta}$ & $\mathbf{t}$ & $\mathbf{s i g}$ & $\mathbf{R}^{2}$ & $\mathbf{F}$ \\
\hline \multirow{2}{*}{$\begin{array}{c}\text { Country -of-origin } \\
\text { image }\end{array}$} & 0.719 & 12.600 & $0.000^{*}$ & 0.518 & 158.770 \\
\cline { 2 - 6 } & 0.642 & 10.200 & $0.000^{*}$ & 0.413 & 104.030 \\
\cline { 2 - 6 } & 0.452 & 6.168 & $0.000^{*}$ & 0.205 & 38.047 \\
\hline
\end{tabular}

Source: author's calculation

**Value is significant at 0.01 level

First, simple regression analysis was performed in order to examine effects of independent variable country -of -origin image on quality, design and attractiveness. Based on obtained results shown in Table 3, it can be concluded that variable country -of -origin image significantly affects perception of product quality, where $\beta=0.719$, and that obtained value is statistically significant with $99 \%$ probability. Also, $51.8 \%$ of dependent variable variability was explained by given regression model. Further, as in the previous case, country -of -origin image influences dependent variable design, where strength of that influence is $\beta=0.642$. The value of $\beta$ coefficient is significant at $\mathrm{p}<0.01$ level, while $41.3 \%$ of dependent variable variability is explained by regression model. Finally, when observing influence of country image on attractiveness, it can be seen that there exists an obvious relationship $(\beta=0.452)$, as well as that obtained value of $\beta$ coefficient is statistically significant at $\mathrm{p}<0.01$ level. 
The observed regression model explains $20.5 \%$ of dependent variable variability. Therefore, based on the above, it can be concluded that quality is most strongly and design the weakest determined by country - of -origin image. Results confirm sub-hypotheses $H 1 a, H 1 b$ and $H 1 c$, which ultimately indicates that first research hypothesis $H 1$ : There is a statistically significant effect of country-of-origin image on product related characteristics, has been proved.

In the next step, effects of observed product related characteristics on consumer loyalty were tested (Table 4). In order for data to be suitable for analysis in multiple regression analysis, it is necessary to meet the multicollinearity condition, which is tested by calculating the VIF coefficient value (Variance Inflation Factor), which must be less than 10 in all pairs of variables (Hair et al., 2014).

Table 4: Multiple regression analysis results (dependent variable: loyalty)

\begin{tabular}{ccccc}
\hline Variable & $\boldsymbol{\beta}$ & $\mathbf{t}$ & sig & VIF \\
\hline Quality & 0.319 & 3.058 & $0.003^{*}$ & 2.353 \\
\hline Design & 0.179 & 1.679 & $0.095^{\star}$ & 2.456 \\
\hline Attractiveness & 0.174 & 2.252 & $0.026^{*}$ & 1.299 \\
\hline
\end{tabular}

Source: author's calculation

*Value is significant at 0.1 level

$R^{2}=0.326 ; F=23.561^{*} ;(p<0.01)$

Table 4 shows results of multiple regression analysis which tested effects of observed product related characteristics on consumer loyalty. The obtained data are suitable for conducting multiple regression analysis because multicollinearity condition is fulfilled, i.e. the VIF coefficient value is less than 5 in all pairs of variables. The value of determination coefficient $\mathrm{R} 2$ shows that $32.6 \%$ of dependent variable variability is explained by observed regression model. The obtained values of $\beta$ coefficient are statistically significant at $\mathrm{p}<0.01, \mathrm{p}<0.1$ and $\mathrm{p}<0.05$ level, i.e. with probabilities of $99 \%, 90 \%$, and $95 \%$, respectively. The strongest influence on dependent variable has characteristic quality $(\beta=0.319)$, followed by design $(\beta=0.179)$, while attractiveness shows the weakest effects on dependent variable $(\beta=0.174)$. According to obtained results, it is concluded that sub-hypotheses $\mathrm{H} 2 a, \mathrm{H} 2 \mathrm{~b}$ and $\mathrm{H} 2 \mathrm{c}$ have been proven, i.e. that hypothesis H2: Product related characteristics have positive effects on development of consumer loyalty, has been proven.

Based on presented results of simple and multiple regression analysis, in the first it can be concluded that independent variable country -of -origin image is statistically significant antecedent of product quality and design and also attractiveness related to using some product. all three observed characteristics showed statistically significant effects on consumer loyalty, as well Based on the above, it is concluded that hypothesis H3: Country-of-origin image shows statistically significant effects on consumer loyalty through characteristics such as quality, design and attractiveness, has been proven. 


\section{CONCLUSIONS}

Empirical research was conducted in order to examine significance of country -of -origin perception on development of attachment, i.e. consumer loyalty, while respecting certain characteristics related to products and their usage. Results of conducted analyzes confirm direct influence of country -of -origin image on quality, design and attractiveness. If we look at the results of previous studies, it can be seen that there is an agreement with results obtained by authors such as Karimov \& El-Murad (2019), Klöckner et al. (2013), Khan et al. (2012) or Kreppel \& Holtbrügge (2012). It is important to point out that influence of country -of -origin image on observed characteristics differs, i.e. it is the strongest when it comes to quality, then design and the weakest when it comes to attractiveness. Then, presence of effects of observed characteristics, first quality, followed by design and attractiveness, on consumer loyalty was determined, which is in line with results of previous studies regarding presence of observed effects (Erdoğmuş \& Büdeyri-Turan, 2012; Esmaeilpour, 2015; Elbedweihy et al., 2016; Mohd Suki, 2017; Kumar et al., 2018; Gómez et al., 2018; Hsu et al., 2018; Shanahan et al., 2019) but also deviates from results obtained by Šapić et al. (2018) which show that consumer loyalty is more strongly determined by design than quality. Finally, according to obtained results, it can be concluded that country -of -origin image has significant effect on consumer loyalty through characteristics such as quality, design and attractiveness, where it is possible to point out similarities with research of Šapić et al. (2018). The obtained research results fulfill existing literature and research related to observed issue and can be applied in practice to formulate appropriate marketing strategies. However, it is important to point out the existence of certain limitations. First of all, sample includes small number of respondents. Also, sample is dominated by women and younger respondents that can have an impact on certain results. The research was conducted only in Kragujevac and its surroundings, which is why opinions of respondents from other parts of the country were not taken into account. Accordingly, recommendation for future research refers precisely to overcoming these limitations, i.e. it is desirable to survey a larger number of respondents from different parts of the country where research is conducted and it is necessary to take into account structure of the sample. Also, future research can measure the effects of country -of -origin influence on consumer behavior before and after the purchase/consumption of the product. In the pre-consumption phase, the research could reflect on the expectations and stereotypes, while in the post-consumption phase the research could focus on the overall product evaluation. Given the number of studies on country -of -origin image and its impact on product perceptions conducted in recent decades, it is safe to say that this is a concept that has significantly attracted attention not only of researchers but also all those who know that this concept can be used in business. This does not only refer to companies, but also governments. Research that deals with this issue, including research conducted in paper, show that image that consumers have of a particular country can significantly affect how they will perceive products originating from that country. Therefore, recommendation is primarily for governments to invest in improving image of their countries, because in that way they raise competitiveness of domestic economy and companies. This can be especially important for underdeveloped and developing countries, because by improving their image, they can improve their position on the international scene. Finally, it is desirable for companies to take into account results of research related to effect of country -of -origin image because it can help them in defining strategies for entering international market. 
ŠAPIĆ. S., LAZAREVIĆ. J., FILIPOVIĆ. J. ^ THE EFFECT OF COUNTRY - OF - ORIGIN IMAGE TROUGH QUALITY, DESIGN AND ATTRACTIVENESS RELATED TO PRODUCT ON CONSUMER LOYALTY

\section{REFERENCES}

Ahmed, S. \& D'Astous, A. (2015). Canada Taiwan differences in product-country perceptions. International Journal of Commerce and Management, 25(1), 38-51. https://doi.org/10.1108/IJCoMA-10-2012-0066

Aichner, T. (2014). Country-of-origin marketing: A list of typical strategies with examples. Journal of Brand Management, 21(1), 81-93. https://doi.org/10.1057/bm.2013.24

Antić, Lj. \& Stevanović, T. (2013). Kvalitet i vreme kao ključni faktori unapređenja konkurentnosti preduzeća. Teme, 37(1), 183-202. http://teme2.junis.ni.ac.rs/public/journals/1/previousissues/teme1-2013/teme1-2013.html

Cilingir, Z. \& Basfirinci, C. (2014). The impact of consumer ethnocentrism, product involvement, and product knowledge on country of origin effects: An empirical analysis on Turkish consumers' product evaluation. Journal of International Consumer Marketing, 26(4), 284-310. https://doi.org/10.1080/08961530.2014.916189

Coudounaris, D. N. (2018). Mediation of product design and moderating effects of reference groups in the context of country-of-origin effect of a luxury brand. Review of International Business and Strategy, 28(2), 169-205. https://doi.org/10.1108/RIBS-05-2017-0044

Elbedweihy, A. M., Jayawardhena, C., Elsharnouby, M. H., \& Elsharnouby, T. H. (2016). Customer relationship building: The role of brand attractiveness and consumer-brand identification. Journal of Business Research, 69(8), 2901-2910. https://doi.org/10.1016/j.jbusres.2015.12.059

Erdoğmuş, İ. \& Büdeyri-Turan, I. (2012). The role of personality congruence, perceived quality and prestige on ready-to-wear brand loyalty. Journal of Fashion Marketing and Management, 16(4), 399-417. https://doi. org/10.1108/13612021211265818

Esmaeilpour, F. (2015). The role of functional and symbolic brand associations on brand loyalty. Journal of Fashion Marketing and Management, 19(4), 467-484. https://doi.org/10.1108/JFMM-02-2015-0011

Esmaeilpour, F. \& Abdolvand, M. A. (2016). The impact of country-of-origin image on brand loyalty: evidence from Iran. Asia Pacific Journal of Marketing and Logistics, 28(4), 709-723. https://doi.org/10.1108/APJML-09-2015-0143

Fornell, C., Johnson, M. D., Anderson, E. W., Cha, J. \& Bryant, B. E. (1996). The American customer satisfaction index: nature, purpose, and findings. Journal of Marketing, 60(4), 7-18. https://doi.org/10.1177/002224299606000403c

Giese, J. L., Malkewitz, K., Orth, U. R. \& Henderson, P. W. (2014). Advancing the aesthetic middle principle: Trade-offs in design attractiveness and strength. Journal of Business Research, 67(6), 1154-1161. https:// dx.doi .org/10.1016/j.jbusres.2013.05.018

Gómez, M., Martín-Consuegra, D., Díaz, E. \& Molina, A. (2018). Determinants and outcomes of price premium and loyalty: A food case study. Journal of Consumer Behaviour, 17(1), 64-74. https://doi.org/10.1002/cb.1692

Gul Gilal, N., Zhang, J. \& Gilal, F. G. (2018). Linking product design to consumer behavior: the moderating role of consumption experience. Psychology Research and Behavior Management, 11, 169-185. https://doi. org/10.2147/PRBM.S161384

Hair, F. Joseph; Black, C. William; Babin, J. Barry; Anderson \& E. Rolph. (2014). Multivariate data analysis. Harlow: Pearson Education Limited.

Hsu, C. L., Chen, Y. C., Yang, T. N., Lin, W. K., \& Liu, Y. H. (2018). Does product design matter? Exploring its influences in consumers' psychological responses and brand loyalty. Information Technology \& People, 31(3), 886-907. https://doi.org/10.1108/ITP-07-2017-0206

Jin, N., Line, N. D. \& Merkebu, J. (2016). The impact of brand prestige on trust, perceived risk, satisfaction, and loyalty in upscale restaurants. Journal of Hospitality Marketing \& Management, 25(5), 523-546. https:// doi.org/10.1080/19368623.2015.1063469

Jobber, D. \& Fahy, J. (2006). Foundations of marketing. New York: McGraw-Hill Inc.

Karimov, F. \& El-Murad, J. (2019). Does country-of-origin matter in the era of globalisation? Evidence from cross sectional data in Uzbekistan. International Journal of Retail \& Distribution Management, 47(3), 262-277. https://doi.org/10.1108/IJRDM-06-2017-0129 
Katsumata, S. \& Song, J. (2015). The reciprocal effects of country-of-origin on product evaluation. Asia Pacific Journal of Marketing and Logistics, 28(1), 92-106. DOI: https://doi.org/10.1108/APJML-04-2015-0059

Khan, H., Bamber, D. \& Quazi, A. (2012). Relevant or redundant: Elite consumers' perception of foreign-made products in an emerging market. Journal of Marketing Management, 28(9-10), 1190-1216. https://doi.or g/10.1080/0267257X.2011.635153

Kim, B. \& Kim, D. (2020). Attracted to or locked in? Explaining consumer loyalty toward Airbnb. Sustainability, 12(7), 1-19. DOI:10.3390/su12072814

Klöckner, H., Langen, N. \& Hartmann, M. (2013). COO labeling as a tool for pepper differentiation in Germany: Insights into the taste perception of organic food shoppers. British Food Journal, 115(8), 1149-1168. DOI: https://doi.org/10.1108/BFJ-07-2011-0175

Kotler, P. \& Keller, K. L. (2016). Marketing Management (15 ${ }^{\text {th }}$ edition). England: Pearson.

Kreppel, H. \& Holtbrügge, D. (2012). The perceived attractiveness of Chinese products by German consumers -A sociopsychological approach. Journal of Global Marketing, 25(2), 79-99. DOI: https://doi. org/10.1080/08911762.2012.72053

Kumar, D. S., Purani, K. \& Viswanathan, S. A. (2018). Influences of 'appscape'on mobile app adoption and m-loyalty. Journal of Retailing and Consumer Services, 45, 132-141. DOI: https://doi.org/10.1016/j.jretconser.2018.08.012

Luchs, M. \& Swan, K. S. (2011). Perspective: The emergence of product design as a field of marketing inquiry. Journal of Product Innovation Management, 28(3), 327-345. DOI: https://doi.org/10.1111/j.1540-5885.2011.00801.x

Maričić, B. (2011). Ponašanje potrošača. Beograd: Centar za izdavačku delatnost Ekonomskog fakulteta.

Marinković, V. (2012). Marketinški aspekti satisfakcije i lojalnosti: Orijentacija na potrošače u savremenom bankarskom poslovanju. Kragujevac: Ekonomski fakultet.

Maguire, M. (2004). Does usability=attractiveness?. In: D. McDonagh., P. Hekkert., J. van Erp \& D. Gyi (eds.), Design and emotion (pp. 303-307). London: Taylor \& Francis Group.

Mohd Suki, N. (2017). Green products usage: structural relationships on customer satisfaction and loyalty. International Journal of Sustainable Development \& World Ecology, 24(1), 88-95. DOI: https://doi.org/1 0.1080/13504509.2016.1169563

Mothersbaugh, D. L. \& Hawkins, D. I. (2016). Consumer behavior: Building marketing strategy. New York: McGraw-Hill Inc.

Munir, A., Ilyas, G., Maming, J. \& Kadir, N. (2020). The role of geo-cultural product attractiveness and acculturative aesthetic attractiveness in enhancing the relationship between innovation and SMEs marketing performance. Management Science Letters, 10(14), 3419-3424. https://doi.org/10.5267/j.msl.2020.5.036

Nagashima, A. (1970). A comparison os Japanese and U.S. attitudes toward foreign products. Journal of Marketing, 34(1), 68-74. https://doi.org/10.2307/1250298

Nunnally, J. C. (1978). Introduction to psychological measurement. New York: McGraw-Hill Inc.

Parkvithee, N. \& Miranda, M. J. (2012). The interaction effect of country-of-origin, brand equity and purchase involvement on consumer purchase intentions of clothing labels. Asia Pacific Journal of Marketing and Logistics, 24(1), 7-22. https://doi.org/10.1108/13555851211192678

Ramaseshan, B. \& Stein, A. (2014). Connecting the dots between brand experience and brand loyalty: The mediating role of brand personality and brand relationships. Journal of Brand Management, 21(7-8), 664-683. https:// doi.org/10.1057/bm.2014.23

Rashid, M. S. (2017). Weakening the effect of unfavorable country of origin: A process-and parameter-associated theoretical framework. Journal of Global Marketing, 30(2), 87-98. https://doi.org/10.1080/08911762.2016.1226450

Šadić, S., Puška, A. \& Beganović, A. (2016). Information support model and its impact on utility, satisfaction and loyalty of users. European Journal of Applied Economics, 13(2), 30-44. https://doi.org/10.5937/ejae13-10675

Šapić, S., Kocić, M. \& Radaković, K. (2018). The effect of a product's country of origin on the customer loyalty creation process. Teme, 42(4), 1297-1317. https://doi.org/10.22190/TEME1804297S 
ŠAPIĆ. S., LAZAREVIĆ. J., FILIPOVIĆ. J. § THE EFFECT OF COUNTRY - OF - ORIGIN IMAGE TROUGH QUALITY, DESIGN AND ATTRACTIVENESS

Shanahan, T., Tran, T. P. \& Taylor, E. C. (2019). Getting to know you: Social media personalization as a means of enhancing brand loyalty and perceived quality. Journal of Retailing and Consumer Services, 47, 57-65. https://doi.org/10.1016/j.jretconser.2018.10.007

Sharma, P. (2011). Country of origin effects in developed and emerging markets: Exploring the contrasting roles of materialism and value consciousness. Journal of International Business Studies, 42(2), 285-306. https:// doi.org/10.1057/jibs.2010.16

Suh, Y., Hur, J. \& Davies, G. (2016). Cultural appropriation and the country of origin effect. Journal of Business Research, 69(8), 2721-2730. https://doi.org/10.1016/j.jbusres.2015.11.007

Thøgersen, J., Aschemann-Witzel, J. \& Pedersen, S. (2020). Country image and consumer evaluation of imported products: test of a hierarchical model in four countries. European Journal of Marketing, ahead-of-print, 55(2), 444-467. https://doi.org/10.1108/EJM-09-2018-0601

Tseng, T. H. \& Balabanis, G. (2011). Explaining the product-specificity of country-of-origin effects. International Marketing Review, 28(6), 581-600. https://doi.org/10.1108/02651331111181420

Veloutsou, C. (2015). Brand evaluation, satisfaction and trust as predictors of brand loyalty: the mediatormoderator effect of brand relationships. Journal of Consumer Marketing, 32(6), 405-421. https://doi. org/10.1108/JCM-02-2014-0878

Zeng, J., Phan, C. A. \& Matsui, Y. (2015). The impact of hard and soft quality management on quality and innovation performance: An empirical study. International Journal of Production Economics, 162, 216-226. https:// doi.org/10.1016/j.ijpe.2014.07.006 


\section{APPENDIX}

Table 5: Variables and corresponding statements

\begin{tabular}{|c|c|}
\hline Variable & Statements \\
\hline \multirow{5}{*}{$\begin{array}{l}\text { Country of origin } \\
\text { image }\end{array}$} & 1. You often check country of origin when buying a certain product. \\
\hline & 2. You prefer to buy a certain product only if it comes from a certain country. \\
\hline & 3. When you buy a new product, the country of origin is the first information you consider. \\
\hline & $\begin{array}{l}\text { 4. If you do not have enough experience with a particular product, the country of origin } \\
\text { helps you make the final decision to purchase that product. }\end{array}$ \\
\hline & 5. You believe that country of origin image determines product quality. \\
\hline \multirow{4}{*}{ Quality } & 6. The country of origin has a great influence on you when it comes to product reliability. \\
\hline & 7. The country of origin has a great influence on you when it comes to product performance. \\
\hline & 8. The country of origin has a great influence on you when it comes to product durability. \\
\hline & 9. The country of origin has a great influence on you when it comes to product functionality. \\
\hline \multirow{4}{*}{ Design } & 10. Products from a certain country are characterized by a recognizable style. \\
\hline & $\begin{array}{l}\text { 11. Products from a certain country are characterized by a large number of models and } \\
\text { colors. }\end{array}$ \\
\hline & 12. Products from a certain country are characterized by a recognizable slogan and logo. \\
\hline & 13. Products from a certain country are characterized by a modern technical solutions. \\
\hline \multirow{5}{*}{ Attractiveness } & 14. Using products from a certain country makes you more attractive in society. \\
\hline & 15. Using products from a certain country makes you recognizable in society. \\
\hline & 16. Using products from a certain country increases your self-confidence. \\
\hline & 17. Using products from a certain country contributes to your style. \\
\hline & 18. Using products from a certain country makes you feel different in society. \\
\hline \multirow{3}{*}{ Loyalty } & $\begin{array}{l}\text { 19. If you are satisfied with products from a certain country, you will continue to buy } \\
\text { them in the future. }\end{array}$ \\
\hline & $\begin{array}{l}\text { 20. If you are satisfied with products from a certain country, you are ready to share } \\
\text { your satisfaction with others and recommend the product. }\end{array}$ \\
\hline & $\begin{array}{l}\text { 21. If you are satisfied with products from a certain country, you are ready to pay } \\
\text { higher price for them. }\end{array}$ \\
\hline
\end{tabular}

Source: authors 


\section{EFEKAT IMIDŽA ZEMLJE POREKLA PREKO KVALITETA, DIZAJNA I ATRAKTIVNOSTI PROIZVODA NA LOJALNOST POTROŠAČA}

\section{Rezime:}

Glavni cilj ovog istraživanja jeste da se utvrdi da li postoji uticaj imidža zemlje porekla na lojalnost potrošača proizvodima koji potiču iz zemalja pozitivnog i prepoznatljivog imidža i da li se taj uticaj ostvaruje preko karakteristika kao što su kvalitet i dizajn proizvoda kao i atraktivnost koju potrošači osećaju usled korišćenja istih. Za ispitivanje ovog uticaja sprovedeno je empirijsko istraživanje na uzorku od 150 ispitanika a analiza prikupljenih podataka izvršena je u softveru SPSS 20. Dobijeni rezultati pokazuju da je informacija o imidžu zemalje porekla proizvoda bitna potrošačima odnosno da ima uticaj na njihovo ponašanje vezano za kupovinu nekog inostranog proizvoda. Preciznije, rezultati pokazuju da imidž zemlje porekla proizvoda utiče na potrošače kada proizvode biraju na osnovu kvaliteta i dizajna istih i atraktivnosti koju potrošači osećaju kada te proizvode koriste, kao i da posredstvom ovih karakteristika imidž zemlje porekla ispoljava efekte na razvoj lojalnosti potrošača. U skladu sa dobijenim rezultatima, nameće se zaključak da je izuzetno poželjno da preduzeća i vlade vode računa o tome kakav imidž njihove zemlje uživaju na svetskom tržištu.

\section{Ključne reči:}

imidž zemlje porekla, kvalitet proizvoda, dizajn proizvoda, atraktivnost, lojalnost potrošača. 